\title{
Innovation and Entrepreneurship: From Schumpeter to Industry 4.0
}

\author{
Vitor Ferreira ${ }^{1,2, a}$ and Ana Lisboa ${ }^{1,2, b^{*}}$ \\ ${ }^{1}$ Superior School of Technology and Management of Leiria, Polythecnic Institute of Leiria, \\ Campus 2, Morro do Lena - Alto Vieiro, 2411-901 Leiria, Portugal \\ ${ }^{2}$ Centre for Rapid and Sustainable Product Development, Polythecnic Institute of Leiria, Rua de \\ Portugal - Zona Industrial, 2430-028 Marinha Grande, Portugal \\ avitor.ferreira@ipleiria.pt, bana.lisboa@ipleiria.pt
}

Keywords: innovation, entrepreneurship, industry 4.0.

\begin{abstract}
Innovation is key to firms' competitive advantage, performance, and growth. In this paper we try to briefly link the concepts of Innovation and Entrepreneurship with the emergence of a new industrial revolution that has been labeled as "Industry 4.0", showing that as in the past a set of innovation are the main drivers for the change of the technical and social paradigm. We summarize a number of concepts to show that the key drivers of competitiveness are Innovation and Entrepreneurship.
\end{abstract}

\section{Introduction}

In an increasingly competitive world where there is a growing search for perfection, innovation emerges as an important area for firms. Not only is it a key factor in achieving the real expectations of firms' clients or target audiences, but it is also acknowledged as a crucial source of competitive advantage, performance and growth $[1,2]$. The relevance of innovation is reflected both in the increasing innovation-related scientific literature, and in the emerging of several political and economic projects involving innovation over the past two decades [3].

Previous works identified distinct types of innovation [e.g. 4], influencing factors, such as environmental and organizational characteristics [e.g. 5] or relationship with partners [6, 7] and innovation results $[8,9,10]$. Notwithstanding the findings of the accumulating literature on this regard, innovation is a complex and systemic phenomenon that involves convoluted interactions between the firm and its environment, and further understanding is needed [11].

This article builds on innovation and addresses the role of a specific strategic orientation, entrepreneurship in its promotion. Furthermore, it examines how both concepts are related to an emerging trend, the 4.0 industry.

\section{Innovation}

It is important to distinguish innovation from invention. Even though related, these concepts are distinct and entail different factors, consequences and challenges. Invention is defined by Schumpeter [12], as an idea, a sketch or a model, for a new or improved product, process or system, which may or may not be patented but which is not yet standardized in the marketplace. It means to generate an idea, a concept, or a solution where there is nothing, to discover something new. Innovation, on its hand, means the adoption of an idea, behavior or invention pertaining to a product, service, device, system, policy or program that is new to the firm [13]. This involves converting the idea, sketch or model invented into a product, service, process or even business that generates value or for which customers are willing to pay for. According to Schumpeter, this conversion process is fundamental to the process of economic development, as something that allows to boost the cycles of growth [12].

Recent studies have sought to establish a conceptual map of innovation in order to define and cover the different forms of understanding and studying the phenomenon. The fields include Economics, Sociology and Management or, alternatively, Cognitive, Organizational or Economic dimensions 
[14]. From Porter, who defines innovation as a set of improvements in technology and in methods or ways of doing things [15] to the broader perspective of the OECD Oslo Handbook which proposes to conceptualize innovation as the implementation of a new or significantly improved product (good or service), process, marketing method or organizational method in business activities, organization place of work or in external relations [16], there have been several definitions. The widening of the concept is also related to the different forms and types of innovation that have been emerging in the literature.

The appearance of these forms and types reflect the innovations' different characteristics and the fact that their adoption is not identically affected by environmental and organizational factors [17]. Particularly, Zaltman identified approximately 20 innovation types [18]. Nevertheless, the most widely studied typology of innovation is product, service and process innovations [17]. Product innovation can manifest as an improvement in machinery for the industrial sector, or as a consumer product. In the point of view of the organization providing the new product, the attraction of the product innovation is that the novelty alone can be suffice to get customers to purchase the product. Service innovation, just like product innovation, is highly important, but it is often overlooked by the consumers, since it doesn't necessarily take a physical form it will seem less attractive. Still, when a service is created where once no market was, like Facebook, YouTube or even Google, it still manages to impress the consumers, sometimes even more than a physical product. Process innovation tends to affect society as a whole. A pertinent example is the manufacturing processes brought forth by Henry Ford in the early 1900's with the Model T. Thanks to the moving assembly line, Ford was able to create affordable vehicles with less manufacturing effort, bringing forth the changing of the manufacturing industry. This example shows that you don't need to necessarily innovate the product, you can achieve the same or even better results by focusing on the process of creation. When considering the degree of novelty associated with the innovation, one can distinguish between incremental and radical innovation [19]. Incremental innovation is described as introducing minor changes to an already existing product, service or process, attempting to achieve a new potential [20]. This can be achieved by changing some components, with the objective of making it cheaper or more reliable, or by simplifying the inner workings of the product. This type of innovation can achieve considerable economic gains over time. Radical innovation happens when an organization makes a new product, service or process that replaces the existing one, for something that is considered as superior [20]. This type of innovation often times affects greatly the market and by consequence the other organizations within that market. Its effects are so vast that it can create new markets, change the existent ones and even make some other products/services useless. Although this categorization has been widely used, Henderson \& Clark alert that it is an incomplete and potentially misleading categorization [21]. A more complete perspective is the transilience map proposed by Abernathy \& Clark who categorize the competitive significance of an innovation into four categories, niche, architectural, regular and revolutionary [22].

Whatever the intensity or type of innovation involved, it stands from a point of wanting to improve, even though the possible outcome might not always be positive [23]. As such, organizations nowadays are investing a large quantity of their time and resources into their research and development departments or developing partnering relationships with customers, suppliers, universities or even competitors [24]. This desire to improve can have many reasons, from efficiency benefits to taking advantage of market needs [25]. Improved products, services and processes may result in synergies, cost reductions and quality / speed of service / health and safety improvements and productivity increase [10]. Furthermore, innovation contributes to expanding firms' product and service range, finding new and better products and discovering new markets [10, 20]. It enables firms to differentiate themselves from competitors [26], which allows them not only to increase their market share and penetration, but also to adapt to market changes and anticipate and protect themselves from unstable or more hostile environments [1, 5]. It is only by innovating that firms can make sure that their customer base is well satisfied, since this process will improve product quality, durability and even reduce the prices. Ultimately, innovation leads to better firm performance [12]. 


\section{Entrepreneurship}

Entrepreneurial firms are imbedded with a philosophy and decision-making processes based on values and behaviors such as innovativeness, proactiveness, risk taking, autonomy and competitive aggressiveness [27, 28]. Innovativeness reflects firms' willingness to embrace new ideas, favor change, support creativity, and encourage experimentation [10]. Proactiveness represents a forwardlooking perspective that aims to identify, anticipate, and pursue future market changes [29]. Risk taking involves firms' availability to take risks and apply resources to pursue opportunities with uncertain outcomes [27]. Autonomy is defined as independent action aimed at advancing a business concept or vision and carrying it through to completion [28]. Competitive aggressiveness represents a combative posture and a forceful response to competitor's actions [28].

These dimensions embody a set of values and beliefs that shape how the firm intends to conduct business and compete [27]. They reflect a willingness to break away from the tried-and-true, take action based on early signals from the environment, accept uncertainty and risk, bring forth a vision, and overcome competitors [28]. The fact that entrepreneurial firms are more prone to supporting experimentation and R\&D investments, creative thinking, and technological leadership enables their department from established practices and technologies [30, 31]. Moreover, their eagerness to anticipate the market and precede competitors not only enhances the chances of developing improvements or extension of existing products, services and processes but also of achieving newto-the-firm and new-to-the-world types of technology, processes, solutions and products. Therefore, entrepreneurship generates a favorable environment in which innovation may sprout [29, 32]. Specifically, there is evidence to suggest that entrepreneurship is a precursor to product, technology, and market innovation [31, 33].

\section{Industry 4.0}

The history of humanity demonstrates how societies with the greatest capacities to create and exploit new knowledge are those that have achieved the greatest wealth. Societies that promote entrepreneurial activities and have a pro-innovation cultural background have long been the birth of both critical innovations and of industrial revolutions [34]. Particularly, innovation is essential within the perspective of economic growth as its achievement implies the introduction of new (and varied) products and services into the economic sphere, impacting different companies', sectors', regions' and countries' scope of capacities and growth potential [3]. In fact it is in the epicenter of the industrial revolutions that have resulted from the exploitation of knowledge, stemming from the scientific and technical revolutions of the 18th and 19th centuries, enabling an ongoing development of new technologies and techniques that resulted in new products, processes and industrial sectors [35].

These industrial revolutions involve major innovations that change the world as it was seen up until then and affect the worldwide economy. Recently the term Industry 4.0 emerged as a revolution to take into account [36]. The idea of having sequential industrial revolutions is not a new concept, since in the field of innovation economics there has long been debate (among authors like Freeman and Perez) the existence of long cycles of economic growth, linked to the dissemination of radical innovations that transform the face of the economy and society [37]. In fact, when analyzed in terms of time, one can identify economic cycles that range from forty to sixty years in length, and where comprised of periods of high sectorial growth economical followed by lower sectorial growth [12, 38]. This cycle effect is known as "Kondratiev waves" or "Kondratiev-Schumpeter long waves". Considering this perspective, the first industrial revolution involved the introduction of the steam engine, and occurred between 1780s and 1840s; the second revolution is related to the railway and steel industries around 1840s-1900s; the third industrial revolution lasted from 1900s and 1950s and was mainly based in the electric and chemical industries; the fourth revolution involved the automobile and petrochemical industries around 1950s and 1990s and the fifth industrial revolution lasted from 1990s to around 2010, and emerged from the information and communications 
technology sectors [39]. The widespread adoption by the global information and communications technology industry paved the way for disruptive approaches to product development, production, and the entire inherent logistics chain. This lead to the sixth industrial revolution, in which we are currently on, that is expected to build around the sustainability, industrial ecology, nanotechnology and biotechnology. In this sense, what got to be known as Industry 4.0 is actually the 6th industrial revolution [40].

Conceptually, Industry 4.0 is centered on the existence of services that fuse the digital and physical components, joining the notion of internet (Machines, devices and sensors connected in a network) with the existence of intelligent systems and their increasing automation [36]. These digital machine networks are organized in a similar way to social networks. Specifically, they connect mechanical and electronic components that, in intelligent machines, continuously share information about current stock levels, problems or failures and changes in orders or levels of demand. In this regard, processes and deadlines are coordinated with the aim of increasing efficiency and optimizing production times and capacity, while improving quality in development, marketing and purchasing. These networks connect not only machines with machines, but create an intelligent network of machines, assets, ICT systems, intelligent products and individuals throughout the value chain and product life cycle [39, 40]. According to a Boston Consulting Group report regarding the implementation of the 4.0 Industry in Germany, four areas will benefit from it, namely productivity, revenue, employment and investment [41]. Productivity is expected mainly in the manufacturing industry due to improvements on conversion costs. Revenue will tend to grow due to the demand of quality and customized goods, as well as demand for enhanced equipment, data analysis and application software. Employment levels - particularly qualified labor such as mechanical engineering and IT - is expected to grow in the first decade of 4.0 Industry deployment. Finally, investment is needed to incorporate the needed changes in firms'production lines and to generate firms that will use these technologies.

\section{Conclusion}

Innovation is widely recognized as crucial for firms operations and performance. Applied to products, services, processes or other areas, more incremental or more radical, it is associated to numerous benefits, both from a financial point of view and for a marketing perspective. Though the phenomenon has attracted researchers', managers' and policy makers' attention, it is a complex and systemic phenomenon that needs further understanding [11].

Specific postures and strategic orientations, such as entrepreneurship appear to favor innovation, given the promotion of an environment characterized by experimentation, forward thinking, risk tolerance, autonomy and competitive aggressiveness. In fact, economies that invest in promoting entrepreneurial practices and developing a pro-innovation cultural background are more likely to innovate and be at the center of industrial revolutions [34].

\section{Acknowledgements}

This work is supported by the Fundação para a Ciência e a Tecnologia (FCT) and Centro2020 through the Project references: UID/Multi/04044/2013 and PAMI - ROTEIRO/0328/2013 (N 022158). 


\section{References}

[1] G.S. Day, The capabilities of market-driven organizations, Journal of Marketing. 58, 4 (1994) $37-52$.

[2] M.A. Peteraf, The cornerstones of competitive advantage: a resource-based view, Strategic Management Journal. 14, 3 (1993) 179-191.

[3] J. Fagerberg, What do we know about innovation? Lessons from the TEARI project, Working Papers on Innovation Studies, Centre of Technology, Innovation and Culture, University of Oslo (2004).

[4] W.J. Abernathy, K.B. Clark, Innovation: Mapping the winds of creative destruction, Research Policy. 14, 1 (1985) 3-22.

[5] J.J. Jansen, F.A. Van Den Bosch, H.W. Volberda, Exploratory innovation, exploitative innovation, and performance: Effects of organizational antecedents and environmental moderators, Management Science. 52, 11 (2006) 1661-1674.

[6] C.A. Un, K. Asakawa, Types of R\&D collaborations and process innovation: The benefit of collaborating upstream in the knowledge chain, Journal of Product Innovation Management. 32, 1 (2015). 138-153.

[7] C. Baldwin, E. Von Hippel, Modeling a paradigm shift: From producer innovation to user and open collaborative innovation, Organization Science, 22, 6 (2011) 1399-1417.

[8] M.S. Yadav, J.C. Prabhu, R.K. Chandy, Managing the future: CEO attention and innovation outcomes, Journal of Marketing. 71, 4 (2007) 84-101.

[9] S. Laforet, Organizational innovation outcomes in SMEs: Effects of age, size, and sector, Journal of World Business. 48, 4 (2013) 490-502.

[10] P.M. Simpson, J.A. Siguaw, C.A. Enz, Innovation orientation outcomes: The good and the bad, Journal of Business Research. 59, 10 (2006) 1133-1141.

[11]K. Smith, Innovation as a systemic phenomenon: rethinking the role of policy, Enterprise and Innovation Management Studies. 1, 1 (2000) 73-102.

[12] J.A. Schumpeter, Business cycle, vol.1, McGraw-Hill, New York, 1939.

[13]F. Damanpour, S. Gopalakrishnan, The dynamics of the adoption of product and process innovations in organizations, Journal of Management Studies. 38, 1 (2001) 45-65.

[14]J. Perdomo-Ortiz, J. Gonzalez-Benito, J. Galende, The intervening effect of business innovation capability on the relationship between Total Quality Management and technological innovation, International Journal of Production Research. 47, 18 (2009) 5087-5107.

[15] M. Porter, Vantagem Competitiva: Criando e Sustentando um Desempenho Superior, Elsevier, Rio de Janeiro, 1989.

[16] OECD - Organization of Economic Cooperation and Development, Frascati Manual. Proposed Practice for Surveys on Research e Experimental Development. OECD, Paris, 2005.

[17] F. Damanpour, R.M. Walker, C.N. Avellaneda, Combinative effects of innovation types and organizational performance: A longitudinal study of service organizations, Journal of Management Studies. 46, 4 (2009) 650-675.

[18] G. Zaltman, R. Duncan, J. Holbek, Innovations and Organizations, Wiley New York, 1973.

[19] W.J. Abernathy, J.M. Utterback, Patterns of industrial innovation, Technology Review. 80, 7 (1978) 40-47. 
[20] K. Atuahene-Gima, Resolving the capability-rigidity paradox in new product innovation, Journal of Marketing. 69, 4, (2005) 61-83.

[21] R.M. Henderson, K.B. Clark, Architectural innovation: The reconfiguration of existing product technologies and the failure of established firms, Administrative Science Quarterly. (1990) 9-30.

[22] W.J. Abernathy, K.B. Clark, Innovation: Mapping the winds of creative destruction. Research Policy. 14, 1 (1985) 3-22.

[23] G. Dosi, Sources, procedures, and microeconomic effects of innovation. Journal of Economic Literature (1988) 1120-1171.

[24] D. Faems, B. Van Looy, K. Debackere, Interorganizational collaboration and innovation: Toward a portfolio approach, Journal of Product Innovation Management. 22, 3 (2005) 238-250.

[25] S. Maryville, Entrepreneurship in the Business Curriculum, Journal of Education for Business. 68, 1 (1992) 27-31.

[26] C. Cooper, Relevance of innovation studies to developing countries, in Technology and Innovation in the International Economy, Edward Elgar, 1994, pp. 1-40.

[27] J.G. Covin, D.P. Slevin, Strategic management of small firms in hostile and benign environments, Strategic Management Journal. 10, 1 (1989) 75-87.

[28] J.G. Covin, W.J. Wales, The measurement of entrepreneurial orientation, Entrepreneurship Theory and Practice, 36, 4 (2012) 677-702.

[29] A. Rauch, J. Wiklund, G.T.T. Lumpkin, M. Frese, Entrepreneurial orientation and business performance: an assessment of past research and suggestions for the future, Entrepreneurship Theory and Practice. 33, 3 (2009). 761-787.

[30] G.J. Avlonitis, H.E. Salavou, Entrepreneurial orientation of SMEs, product innovativeness, and performance, Journal of Business Research. 60, 5 (2007) 566-575.

[31] A. Lisboa, D. Skarmeas, C. Lages, Entrepreneurial orientation, exploitative and explorative capabilities, and performance outcomes in export markets: A resource-based approach, Industrial Marketing Management. 40, 8 (2011) 1274-1284.

[32] G.T.T. Lumpkin, G.G. Dess, Clarifying the entrepreneurial orientation construct and linking it to performance, Academy of Management Review. 21, 1 (1996) 135-172.

[33] K.Z. Zhou, C.K. Yim, D.K. Tse, The effects of strategic orientations on technology- and market-based breakthrough innovations, Journal of Marketing. 69, 2 (2005) 42-60.

[34] P.E. Petrakis, P.C. Kostis, D.G. Valsamis, Innovation and competitiveness: Culture as a longterm strategic instrument during the European Great Recession, Journal of Business Research. 68, 7 (2015) 1436-1438.

[35] P. Braunerhjelm, Universities and Regional Development: The Old Versus the New. Mimeo, The Royal Institute of Technology, Stockholm, 2007.

[36] M. Hermann, T. Pentek, B. Otto, Design principles for industrie 4.0 scenarios, in System Sciences (HICSS), 49th Hawaii International Conference, IEEE. 2016, pp. 3928-3937.

[37] C. Freeman, C. Perez, Structural crisis of adjustment, business cycles and investment behavior, in Dosi, G., Freeman, C., Nelson, R., Silverberg, G., Soete, L. (Eds.), Technical Change and Economic Theory, Pinter, London, 1988.

[38] N.D. Kondratiev, The major economic cycles. Moscow, 1925. 
[39] D. Seebode, S. Jeanrenaud, J. Bessant, Managing innovation for sustainability, R\&D Management. 42, 3 (2012) 195-206.

[40] C. Freeman, F. Louçã, As time goes by: From the Industrial Revolutions to the Information Revolution, Oxford University Press, 2001.

[41] M. Rüßmann, M. Lorenz, P. Gerbert, M. Waldner, J. Justus, P. Engel, M. Harnisch, Industry 4.0: The future of productivity and growth in manufacturing industries, Boston Consulting Group, 2015. 